\title{
Landscaping pebbles attract nesting by the native ground- nesting bee Halictus rubicundus (Hymenoptera: Halictidae)
}

\author{
James H. CANE \\ USDA-ARS Pollinating Insect Research Unit, Utah State University, Logan, UT 84322-5310, USA
}

Received 12 January 2015 - Revised 27 February 2015 - Accepted 11 March 2015

\begin{abstract}
Most species of bees nest underground. Recent interest in pollinator-friendly gardens and landscaping focuses on planting suitable flowering species for bees, but we know little about providing for the ground-nesting needs of bees other than leaving them bare dirt surfaces. In this study, a surface layer of decorative flat stream pebbles was experimentally deployed in 24 paired subplots amid a nesting aggregation of the bee Halictus rubicundus . Over 2 years, females consistently preferred to nest amid the pebbles rather than adjacent bare dirt. Species of Halictus and their relatives (Lasioglossum, Dialictus ) are widespread native floral generalists found in many urban areas of the northern hemisphere. Discovery of this practical soil nesting enhancement for H. rubicundus offers an aesthetically acceptable landscaping technique to promote these bees' nesting, particularly where pollinator gardens and bee-friendly landscaping is already being provided.
\end{abstract}

pollinator / bees / mulch / garden design / landscape / urban / conservation

\section{INTRODUCTION}

In recent years, pollinator conservation has attracted growing public enthusiasm. Native bees are the predominant wild floral visitors and pollinators in nearly all habitats, although in many agricultural landscapes, managed European honeybees often prevail where hives are deployed. Unlike most flower-visiting insects (e.g., butterflies), bees require two independent habitats: (1) a suitable nesting substrate (e.g., often soil, but also deadwood, or pithy or hollow twigs) and (2) attractive floral hosts where nesting females can collect pollen and nectar to provision their offspring. Informed advice for good plant choices, garden bee traits, and commercially available plant materials (e.g., seeds, transplants) have been proliferating (e.g., Frankie et al. 2014) to enable

Corresponding author: J. Cane,

Jim.Cane@ars.usda.gov

Manuscript editor: Klaus Hartfelder an interested public to successfully grow pollinator-friendly flower gardens and landscaping for bees. In contrast, there is little practical guidance for augmenting soil substrates to foster any of the thousands of native bee species that nest in the ground.

Current landscaping advice to favor groundnesting bees highlights the avoidance of surface and subsurface treatments that are detrimental to bee nesting. Obvious deterrents and barriers to bee nesting include pavements, thick surface mulches, dense turf, and buried landscape fabric. The general recommendation of leaving bare soil (e.g., Frankie et al. 2014) does work to benefit ground-nesting bees, but too much bare soil can be at odds with typical aesthetic and erosioncontrol objectives of landscaping. Moreover, some species avoid bare soil for nesting (Julier and Roulston 2009). Practical, affordable, effective, and visually appealing soil surface treatments are needed that favor ground-nesting bees in gardens and other manicured landscapes.

In this study, I experimentally evaluated using a thin surface mulch of pebbles to attract and retain 
nesting by female Halictus rubicundus (Christ) bees. Their preference for the pebble mulch versus bare soil was measured using nest densities at replicated paired plots in an existing nesting aggregation.

\section{MATERIALS AND METHODS}

\subsection{Bee natural history}

The bee Halictus rubicundus is a widespread native of North America (Soucy 2002) and Europe (Potts and Willmer 1997), where it can be common in both wildlands as well as more anthropogenic settings (e.g., roadsides, cities, gardens). Like most other Halictus species (Michener 1974), it is a primitively eusocial bee; each colony is founded in the spring by a single fertile queen (Yanega 1990). Later in the season, tasks such as foraging, nesting, and defense are gradually assumed by the queen's unmated daughter workers if the growing season is long enough (Soucy 2002). The subterranean nests of Halictus species are often found grouped in persistent aggregations (Potts and Willmer 1997; Yanega 1990; Hogendoorn and Leys 1997; Eickwort et al. 1996). Adult gynes (future queens) emerge in the autumn to mate, then leave the aggregation to pass the winter elsewhere (Yanega 1990). Although old entrances generally are erased by winter weather, in the early spring gynes fly back to the same aggregation site to initiate a new nest near their former natal nest (typically within 1-2 m) (Potts and Willmer 1997; Yanega 1990). Each gyne excavates a new subterranean tunnel that leads to a shallow ( $5 \mathrm{~cm}$ deep) cluster of small bee-sized earthen cavities for their progeny (Potts and Willmer 1997; Eickwort et al. 1996; Soucy 2002). On the surface, she piles up a growing conical heap of the excavated soil (a tumulus) with her tunnel entrance at its center.

\subsection{Experimental design}

The study aggregation was on the campus of Utah State University in Logan Utah USA $\left(41^{\circ} 45^{\prime} \mathrm{W} \times-111^{\circ}\right.$ $18^{\prime} \mathrm{N}$, elev. $1580 \mathrm{~m}$ ). It occupied a 1.5 -m-wide strip of bare earth between a 400-m-long sidewalk and a chain link fence backed to the north by a shady cemetery with turf grass. Nesting by H. rubicundus was concentrated in sunlit areas between scattered shade trees. The aggregation was first noticed in 2011. During June of 2012, 24 rectangular plots $\left(0.5 \mathrm{~m}^{2}\right)$ were delimited amid more populous sunlit parts of the aggregation. Each plot was divided into two equal-sized $0.25-\mathrm{m}^{2}$ subplots $(50 \times 50 \mathrm{~cm})$. Each square subplot of a pair adjoined the sidewalk and shared a common edge. Each subplot corner received a painted nail marker. Active H. rubicundus nests, which are recognizable by their soil tumuli, were first counted on the 24 subplot pairs on July 3 2012, before surface treatment.

\subsection{Nesting response to surface pebble treatment}

Two months later, on August 31, 2012, one subplot of each pair was spread with a monolayer of rounded, flat stream pebbles (Figure 1b). Pebbles were shallowly pressed into place using a pavement tamper. Each control subplot retained its bare soil surface. To characterize the pebble layer, a mockup subplot square of white paper received an equivalent pebble surface. The 96 pebbles in the $50 \times 50-\mathrm{cm}$ square weighed $5.5 \mathrm{~kg}$. A digital image of the mockup was spatially analyzed (ImageJ) (Figure 1a). Pebbles averaged $18+9 \mathrm{~cm}^{2}$ in cross-sectional area and covered $60 \%$ of the soil surface (thus leaving $40 \%$ exposed soil in the subplots receiving pebbles).

The next year (2013), foundress bees began arriving at the aggregation on March 31, about the time of forsythia bloom at the site (midday air temperature $16{ }^{\circ} \mathrm{C}$ ). A month later (April 29), the numbers of initiated $H$. rubicundus nests were counted in all 48 paired subplots. They were counted again on July 22 when males were numerous at nearby flowers. Nest starts were counted again 1 year later on April 112014 (first nests 24 March). The study was ended thereafter, as half of the aggregation was excavated to replace the sidewalk, and most of the rest covered in a thick layer of bark mulch. The difference in nest counts between paired subplots on a given day was calculated and statistically compared using a signed rank test and $\mathrm{Z}$ statistic $\left(\right.$ SigmaPlot $\left.^{\circledR}\right)$.

\subsection{Soil subsurface temperatures in early spring}

Shallow soil temperatures were measured after snowmelt at the aggregation. At midday on March 13, 2013, a soil thermometer was repeatedly pushed $5 \mathrm{~cm}$ deep into the sunlit moist soil of the aggregation at seven subplot pairs, both amid the pebble mulch and the adjacent bare dirt surfaces. A young H. rubicundus queen generally makes her springtime cluster of nest 


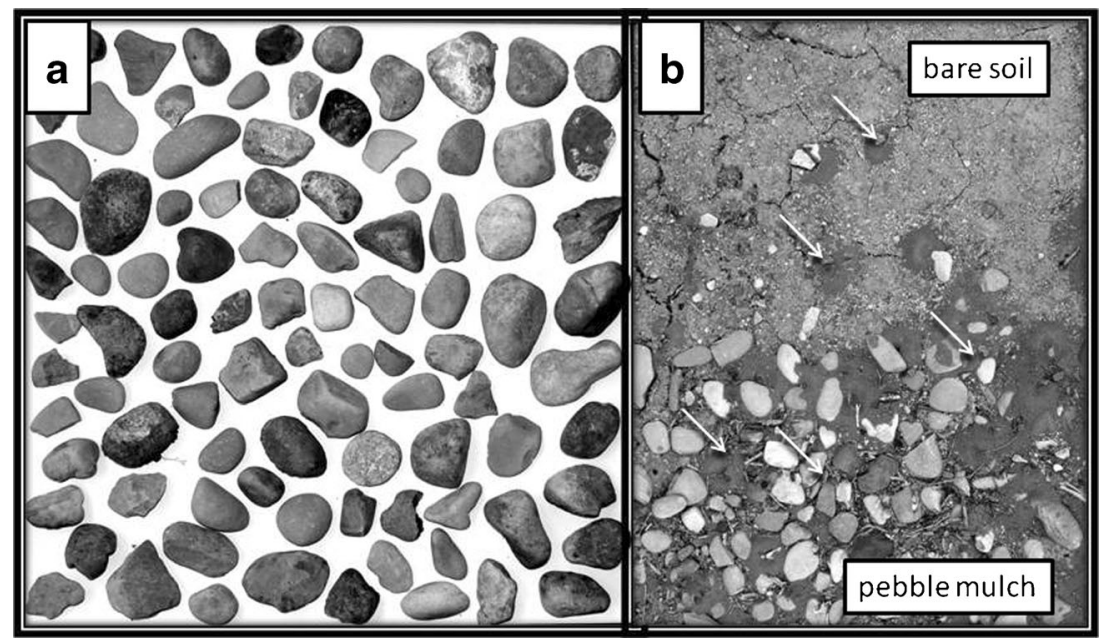

Figure 1. The physical distribution and appearance of the stream pebble mulch: a arrayed to scale on a white background for digitization and $\mathbf{b}$ nest tumulus densities, comparing the bare dirt control (above) with the pebble mulch subplot (below). Note the greater number of nest soil heaps (some shown with arrows) amid the pebble mulch.

cells at this depth (Potts and Willmer 1997; Soucy 2002). Air temperature was also recorded.

\section{RESULTS}

\subsection{Pretreatment nesting}

In the year before experiment (2012), nests of H. rubicundus were equally numerous between subplot pairs (Figure 2), averaging 14.2+12 and 14.4+9 nests, respectively. Differences in nest numbers between subplot pairs were generally small and without bias as to a given side (Figure 3). Original nest densities ranged from 2 to 46 nests per $1 / 4-\mathrm{m}^{2}$. The median difference in nest densities between subplot pairs was only two nests. These closely similar nest densities in subplot pairs mostly reflected care in plot placement. After nest activity had ceased for the autumn, 24 subplots received a surface mulch of pebbles, while its paired subplot remained bare soil.

\subsection{Bees' nesting responses to the pebble mulch}

The following April (2013), $78 \%$ of the returning foundress females (gynes) chose to start their nests amid the pebble mulch subplot
(Figure 2) rather than in the like-sized bare soil squares. Nest entrance densities ranged from 0 to 70 nests per $1 / 4-\mathrm{m}^{2}$. At every one of the 24 plots, more new $H$. rubicundus nests were found amid the pebble mulch surface treatment than its paired bare soil control (mean 24 vs 7 nests per subplot, $\mathrm{Z}=-4.29, P \leq 0.001$ ) (Figure 3). Later, in July, mature nests continued to always be more numerous in the pebble subplot than the bare soil side (mean 10 vs 4.4 nests). Active nests at this time were more difficult to recognize, both because holes had accumulated as well as tumuli having washed away. A year later, in April 2014, more returning gynes again chose to nest amid the pebble treatment over the bare soil side in every one of the 24 plots (mean 31 vs 17 nests per subplot, $\mathrm{Z}=-4.29, P \leq 0.001$ ) (Figure 2).

\subsection{Soil subsurface temperatures in early spring}

Shallow soil temperatures differed little between pebble surfaces and bare soil before gynes returned to the aggregation. On March 13, 2013, a sunny day with a noon-time air temperature of $1{ }^{\circ} \mathrm{C}$, soils $5 \mathrm{~cm}$ below the surface were consistently warmer than the air above (soil mean $11^{\circ} \mathrm{C}$, range $8.3-12.7{ }^{\circ} \mathrm{C}$ ). However, soil temperatures 


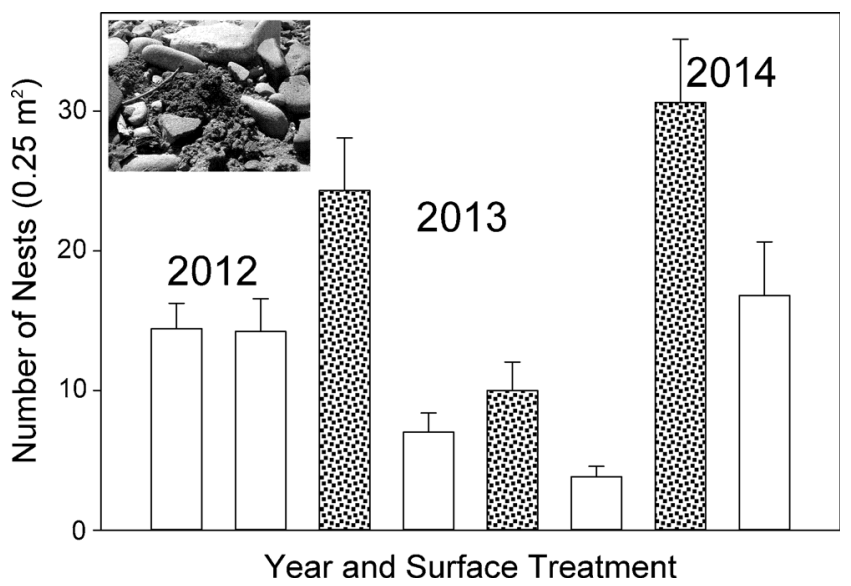

Figure 2. Average nesting densities in the $0.25-\mathrm{m}^{2}$ subplots. Nests in the 2012 survey were counted prior to adding the surface treatment. For the 2013 and 2014 surveys, bars with a patterned fill are for nest counts in the squares with the pebble surface treatment. Inset nest tumulus of H. rubicundus amid stream pebbles.

differed little (mean $0.4^{\circ} \mathrm{C}$ ) beneath mulched and adjacent bare soil surfaces. Two weeks after this thermal survey, the first overwintering gynes of H. rubicundus began arriving at the aggregation.

\section{DISCUSSION}

During the months preceding application of the pebble mulch surface, the bee $H$. rubicundus nested at more or less equal densities in the paired bare soil subplots. In the two subsequent years (and generations), 66-78\% of returning gynes preferred to build their nests in the subplots that received the pebble mulch surface. Later in the first summer, $70 \%$ of mature nests in the plots were on the side with the pebble mulch surface.

Several other studies report the association of some species of halictid bees with surface stones, gravel, or surface irregularities, all of them genera common in urban bee surveys. In Scotland, H. rubicundus often located their nest entrances close to stones which warmed the soil (Potts and

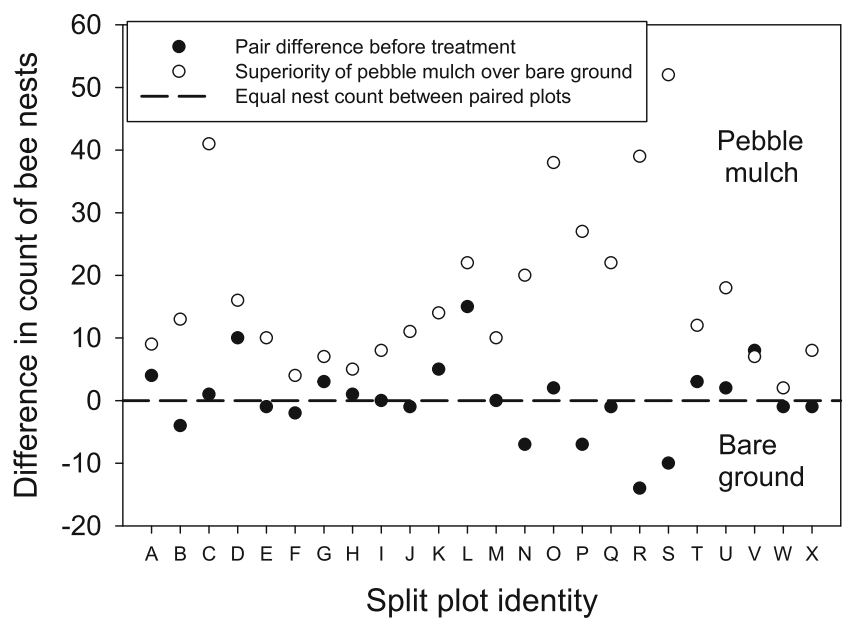

Figure 3. Scatterplot of the differences in nest counts between each pair of plots (in order, starting from the westernmost plot) before treatment and then the year after the pebble treatment was applied to one of each of the 24 subplot pairs. 
Willmer 1997). Nesting aggregations of $H$. rubicundus have been studied in a rock garden and along an unpaved gravel roadway, where bees likewise nested amid pebbles and stones (Soucy 2002). Female H. ligatus preferentially placed their entrances against basal plant rosettes (Packer and Knerer 1986), a useful trait in gardens. On Cape Breton Island, Canada, the halictid bees Augochlorella striata, Evylaeus cinctipes, and $E$. comagenense all situated their nest entrances next to surface stones, which were found to warm the adjacent soil (Packer et al. 1989). A fourth species, Dialictus laevissimum, nested without regard to surface stones. Three species of Agapostemon nesting in an insectary consistently chose to nest under provided stones (Roberts 1969). The bee Dieunomia triangulifera preferred to situate their nests near visual surface landmarks and amid surface irregularities (Wuellner 1999). The alkali bee, $N$. melanderi, nests in natural or man-made featureless saltpans (Fronk and Painter 1960; Cane 2008), but where sparse plants are present, Fronk and Painter (1960) reported that the first females consistently chose to nest by a plant stem. A diverse group of halictid bees places their nest entrances against stones; many of these genera are frequent in garden settings.

The habit seems poorly known or obscure in reports from other bee families. The squash bee, Peponapis pruinosa (Apidae), was shown to avoid bare soil when it can nest beneath squash leaves or vines lying on the soil surface (Julier and Roulston 2009). Many other bees regularly nest amid flat, seemingly uniform bare soil surfaces, such as are found in sand flats, floodplains, saltpans, and the like (e.g., Colletes ). In general, though, the proximity of nest entrances to surface features and irregularities is not commonly mentioned in descriptions of bee nesting biologies (e.g., Cane et al. 1996). In light of this study, they should be noted, quantified, and considered for experimental manipulation.

Many species of Halictus bees tolerate urbanization. They have been reported from many urban bee surveys, particularly in the north temperate zone, including cities in Japan, Germany, Belgium, Canada, and the USA (references in Table 5.1 of Cane 2005; also Tommasi et al. 2004; Matteson et al. 2008; Kearns and Oliveras
2009; Frankie et al. 2005). Other halictids that are also floral generalists and also nest in the soil, notably Lasioglossum sensu stricto, Evylaeus and Dialictus, were often numerous in these same studies of urban bee faunas; indeed, it would be the rare urban bee study that found any bees at all but lacked halictids. Some Dialictus and Evylaeus are social like Halictus. Those surveys that netted bees at flowers found that, as expected, these halictid bee taxa were invariably taken at a wide diversity of available native and exotic flowers, both cultivated and wild or feral. Hence, these bees are versatile foragers that can take advantage of many flower garden blooms if given the chance to nest nearby.

Why do so many returning gynes of Halictus prefer to start their nests amid pebble mulch rather than the bare soil of the rest of their aggregation? Larger sunlit stones can have thermal advantages, absorbing more solar radiation than bare soil, or holding heat better after nightfall. In the aggregations of halictid bees in the Cape Breton study, soils of nests beneath larger stones were $2-3{ }^{\circ} \mathrm{C}$ warmer all afternoon at $5-\mathrm{cm}$ depth. The bee Lasioglossum duplex (reported as Halictus duplex) preferred to nest amid sunlit, warmer soils (Sakagami and Hayashida 1961). A similar question has been experimentally studied with cavitynesting bees of the genus Ceratina. Two species both preferred sunlit over shaded nesting substrates, sunlit substrates resulting in more and larger progeny for one of the species (Vickruck and Richards 2012). Social Halictus commence nesting in early spring, when air temperatures in their northern ranges are marginally warm for flight $\left(1^{\circ} \mathrm{C}\right)$ and soon after snow has melted away (in northern Utah, at least). Although soils at 5-cm depth under pebble mulch or bare soil were equally warm at the Logan Utah site in March, other subtle thermal advantages were not explored (sunlit surface temperatures to better warm alighting or preflight bees, thermal inertia after dark, etc.).

Other nesting advantages of pebble mulches warrant additional experiment. Soils at the Logan aggregation were all moist or saturated at the start of nesting in Logan, owing to water percolation from recently melted snowdrifts. Any advantages for better soil moisture retention under the pebble mulch would only manifest later in the dry 
summer months. Pebble arrays represent the kinds of persistent visual landmarks that halictid bees use for nest localization (Brünnert et al. 1994), particularly useful for bees where rain or irrigation removes nest tumuli. Lastly, positioning a nest entrance next to a pebble, small stone, or grass clump might lessen the risk of nest entrance closure resulting from tumulus cave-ins or foot traffic, although there could be disadvantages too (e.g., for grass clumps, tangled grass roots). The advantage gained by $H$. rubicundus nesting amid the pebble surface is not evident, but their nesting preference for a pebble surface was undeniable.

Do fitness advantages accrue to the gynes that choose to nest amid a pebble mulch? Individual nests were not marked; so, their fates could not be tracked. The greater retention (persistence) of active nests late into the summer amid the pebble mulch than the bare soil is one proxy for fitness, as it was the season of gyne and male reproduction. The ultimate measure of fitness would be gynes (and males) produced per nest, but gynes are not physically distinct from workers active in the same nests. Moreover, briefly collecting gynes would likely have disrupted the orientation flights needed to learn how to return to their part of the aggregation the following spring, as shown by Yanega (1990).

Decorative stream pebble mulches, if applied thinly as described here, were shown to attract nesting by resident female $H$. rubicundus; pebble mulches also attract colonists. My observed colonization of a new campus xeriscape garden was the inspiration for this experimental study. That garden site had been lawn, then excavated for buried utility repairs. Hence, it could not have had any resident bees. Thereafter, a xeriscape garden was created with scattered berms that were planted with attractive native flowering perennials. The surface was thinly strewn with a mulch of stream pebbles. A year later (2011), a few nests of $H$. rubicundus appeared amid the pebble mulch. The population has since multiplied to hundreds of bees, persisting for the past 5 years. The colonists likely flew from elsewhere on campus, given that several other aggregations of this bee are known in campus.

Other aesthetically appealing soil surface options will likely attract nesting by $H$. rubicundus . At a neighborhood aggregation in Logan, these bees have nested amid a sunlit monolayer of rounded rock cobble (grapefruit-sized). This aggregation has persisted for 13 years but is lately dwindling as weedy annuals have been allowed to proliferate, shading the surface. Related halictid bees placed their nests next to or even under surface stones (Packer et al. 1989). Many opportunities exist to evaluate practical modifications of soil surfaces to make our pollinator gardens more welcoming to native bees. Suitable, attractive nest sites in the vicinity of season-long gardens of suitable floral bloom constitute the simple recipe for propagating urban populations of native bees such as H. rubicundus .

\section{ACKNOWLEDGMENTS}

Byron Love, Chris McGlone, and Liesl Cannon helped with the setup and monitoring of this experiment. Helpful reviews were provided by Carolina Simao and Richard Toth.

Des cailloux utilisés pour l'aménagement paysager favorise la nidification de l'abeille indigène nichant dans le sol, Halictus rubicundus (Hymenoptera: Halictidae)

pollinisateur / mulch / jardin / paysage / zone urbaine / conservation

Steine strukturieren die Landschaft und stimulieren die bodennistende Biene Halictus rubicundus (Hymenoptera: Halictidae) zum Nestbau

Bestäuber / Bienen / Mulch / Gartenanlage / Stadt / Artenschutz

\section{REFERENCES}

Brünnert, U., Kelber, A., Zeil, J. (1994) Ground-nesting bees determine the location of their nest relative to a landmark by other than angular size cues. J. Comp. Physiol. A Sens. Neural Behav. Physiol. 175, 363-369

Cane, J.H. (2005) Bees, pollination, and the challenges of sprawl. In: Johnson, E., Klemens, M. (eds.) Nature in Fragments: The Legacy of Sprawl, pp. 109-124. Columbia Univ. Press, New York

Cane, J.H. (2008) A native ground-nesting bee (Nomia melanderi) sustainably managed to pollinate alfalfa across an intensively agricultural landscape. Apidologie 39, 315-323 
Cane, J.H., Schiffhauer, D., Kervin, L.J. (1996) Pollination, foraging, and nesting ecology of the leaf-cutting bee Megachile (Delomegachile) addenda (Hymenoptera: Megachilidae) on cranberry beds. Ann. Entomol. Soc. Am. 89, 361-367

Eickwort, G.C., Eickwort, J.M., Gordon, J., Eickwort, M.A. (1996) Solitary behavior in a high-altitude population of the social sweat bee Halictus rubicundus (Hymenoptera: Halictidae). Behav. Ecol. Sociobiol. 38, 227-233

Frankie, G.W., Thorp, R.W., Schindler, M., Hernandez, J., Ertter, B., Rizzardi, M. (2005) Ecological patterns of bees and their host ornamental flowers in two northern California cities. J. Kansas Entomol. Soc. 78, 227-246

Frankie, G.W., Thorp, R.W., Coville, R.E., Ertter, B. (2014) California Bees and Blooms: A Guide for Gardeners and Naturalists. Heyday Books, Berkeley

Fronk, W.D., Painter, L.I. (1960) Some characteristics of alkali bee nesting sites. J. Econ. Entomol. 53, 424-425

Hogendoorn, K., Leys, R. (1997) Life-cycle of Halictus rubicundus Christ (Hymenoptera : Halictidae) in the Netherlands: Comparison of two populations. J. Kansas Entomol. Soc. 70, 347-352

Julier, H.E., Roulston, T.H. (2009) Wild bee abundance and pollination service in cultivated pumpkins: farm management, nesting behavior and landscape effects. J. Econ. Entomol. 102, 563-573

Kearns, C.A., Oliveras, D.M. (2009) Environmental factors affecting bee diversity in urban and remote grassland plots in Boulder, Colorado. J. Insect Conserv. 13, 655-665

Matteson, K.C., Ascher, J.S., Langellotto, G.A. (2008) Bee richness and abundance in New York city urban gardens. Ann. Entomol. Soc. Am. 101, 140-150

Michener, C.D. (1974) The Social Behavior of the Bees: a Comparative Study. Harvard University of Press, Cambridge
Packer, L., Knerer, G. (1986) An analysis of variation in the nest architecture of Halictus ligatus in Ontario Canada. Insect. Soc. 33, 190-205

Packer, L., Sampson, B.J., Lockerbie, C., Jessome, V. (1989) Nest architecture and brood mortality in four species of sweat bee (Hymenoptera, Halictidae) from Cape Breton Island Nova Scotia, Canada. Can. J. Zool. 67, 2864-2870

Potts, S.G., Willmer, P. (1997) Abiotic and biotic factors influencing nest-site selection by Halictus rubicundus, a ground-nesting halictine bee. Ecol. Entomol. 22, 319-328

Roberts, R.B. (1969) Biology of the bee genus Agapostemon (Hymenoptera: Halictidae). Univ. Kans. Sci. Bull. 48, 689-719

Sakagami, S.F., Hayashida, K. (1961) Biology of the primitive social bee, Halictus duplex Dalla Torre III. Activities in spring solitary phase. J. Fac. Sci. Hokkaido Univ. Ser VI Zool. 14, 639-682

Soucy, S.L. (2002) Nesting biology and socially polymorphic behavior of the sweat bee Halictus rubicundus (Hymenoptera: Halictidae). Ann. Entomol. Soc. Am. 95, 57-65

Tommasi, D., Miro, A., Higo, H.A., Winston, M.L. (2004) Bee diversity and abundance in an urban setting. Can. Entomol. 136, 851-869

Vickruck, J.L., Richards, M.H. (2012) Niche partitioning based on nest site selection in the small carpenter bees Ceratina mikmaqi and C. calcarata. Anim. Behav. 83, 1083-1089

Wuellner, C.T. (1999) Nest site preference and success in a gregarious, ground-nesting bee Dieunomia triangulifera. Ecol. Entomol. 24, 471-479

Yanega, D. (1990) Philopatry and nest founding in a primitively social bee, Halictus rubicundus. Behav. Ecol. Sociobiol. 27, 37-42 